\title{
AVALIAÇÃO TÉCNICO ECONÔMICA: UM ESTUDO DE CASO DA ATIVIDADE LEITEIRA NA FAZENDA OLHOS D’ ÁGUA
}

\author{
SOUZA, Patrick Vilela de ${ }^{1}$ \\ VALENTIM, Jean Kaique ${ }^{2}$ \\ VILELA, Fernanda Fonseca ${ }^{1}$ \\ CAMPOS, Claudia Aparecida ${ }^{1}$
}

\begin{abstract}
Recebido em: 2019.08.28 $\quad$ Aprovado em: 2020.03.16 $\quad$ ISSUE DOI: $10.3738 / 21751463.3662$
\end{abstract}
Resumo: Objetivou-se, com o desenvolvimento deste trabalho, avaliar os dados referentes aos índices econômicos e zootécnicos para analisar a rentabilidade da atividade leiteira da Fazenda Olhos D'Água, no período de janeiro de 2013 a dezembro de 2015. Foi realizada uma pesquisa descritiva especificamente um estudo de caso, para o levantamento dos dados necessários à realização da pesquisa. Os dados zootécnicos foram cadastrados no software Prodap-Profissional e os econômicos em tabelas do programa Balde Cheio. Foi realizado a correlação dos dados zootécnicos com os econômicos no período analisado, visando identificar os itens técnico econômico que mais afetam a eficiência e rentabilidade da atividade. Dos componentes do custo operacional efetivo, a alimentação e a mão-de-obra foram que mais contribuíram no aumento do mesmo. Pode-se observar que com a diminuição da produção de leite na propriedade no período avaliado, provenientes das tomadas de decisão do produtor, o custo total teve um grande aumento, devido as depreciações e remuneração do capital ser muito semelhante com a produção alta, média ou baixa. O preço do litro de leite recebido durante os três anos avaliados não houve grande diferença, mantendo muito estável. Nos dois primeiros anos avaliados, a atividade teve a maioria da receita proveniente de venda de vacas em lactação, e uma pequena quantidade de animais produtivos em relação ao rebanho, o que fez com que a atividade ficasse um pouco arriscada. Mas, a partir dos resultados alcançados nas análises, pode-se concluir que a atividade é viável, e que se encontra estruturada para os próximos anos.

Palavras chave: Atividade leiteira, Custo de produção, Índices zootécnico e econômicos.

\section{TECHNICAL ECONOMIC EVALUATION: A CASE STUDY OF THE DAIRY ACTIVITY ON FARM WATER EYES}

SUMMARY: The objective of the development of this work, analyze data regarding the costs, revenues and performance indexes from Eyes D Farm "Water, from January 2013 to December 2015 was performed the correlation of livestock performance data with economic in the period analyzed. We sought to identify the economic technical items that most affect the efficiency and profitability. The components of the effective operational cost, food and labor were that contributed to it. We can see that with the decrease in milk production on the property during this period, the total cost has greatly increased, due to depreciation and return on capital is very similar to the high production, medium or low. The price of a liter of milk received during the three years evaluated not hear big differences, maintaining very stable in the first two years of evaluation activity had most of the revenue from sale of dairy cows and a small amount of productive animals for the flock, which made the activity to stay a bit risky, but it was a viable activity, which is well structured for the coming years.

Keywords: Cost of production, Dairy activity, Livestock and economic indices. 


\section{INTRODUÇÃO}

A exploração da pecuária de leite no Brasil é uma atividade muito importante no setor agropecuário e é fundamental para o progresso econômico do país. Minas Gerais é o maior estado produtor de leite do país (IBGE, 2016). Porém, existem diferentes sistemas de produção que podem interferir no resultado final. Este fato, pode levar ao questionamento da viabilidade econômica da atividade.

Os levantamentos econômicos e zootécnico, e a produção de leite dentro dos padrões exigidos de qualidade pela instrução normativa 62, são imprescindíveis para o produtor tomar decisões de forma mais correta. Entretanto, o cálculo do custo de produção do leite é uma tarefa muito complexa e demorada, pois são muitos números gerados na atividade que requerem muita atenção e um conhecimento razoável. Entretanto, é compensatório este trabalho, pelo fato de gerar um nível de conhecimento no processo e facilitar a tomada de decisão.

O levantamento dos indicadores de eficiência econômica e zootécnica, permite ao produtor analisar seus índices com a literatura, como exemplo podemos citar o indicador intervalo entre partos, na literatura se diz que o ideal é em torno de doze meses, com este dado se sabe se este índice está coerente, se pode melhorar ou não, e buscar ajuda de como melhorar tal índice, com profissionais da área.

Neste contexto as estimativas de custos de produção se tornam uma ferramenta que auxiliará o produtor nas tomadas de decisão de seu negócio. A estimativa dos custos de produção é o detalhamento de todas as despesas e receitas diretas ou indiretas das atividades produtivas envolvidas (GOTTSCHAL et al., 2002).

O custo de produção é um instrumento neinstrucessário para o administrador da atividade leiteira. Entretanto, seu cálculo envolve algumas questões simples, outras nem tanto, razão pela qual seu uso é pouco praticado, se a metodologia do cálculo deste custo não for conhecida, esta viabilidade pode ser estimada de maneira incorreta chegando a conclusões equivocadas (GOMES, 2000).

Este custo é um dos principais fatores a ser analisado para a boa administração de uma empresa, com ele pode-se estimar a viabilidade econômica de um negócio, em função do capital investido ou compará-lo com outras atividades agropecuárias ou não (FARIA, 2005).

Segundo este mesmo autor, a realidade mostra que o produtor brasileiro ainda não sabe estimar seu lucro, ficando preocupado apenas em cobrir seus custos operacionais.

Os dados obtidos da apuração dos custos de produção têm sido utilizados para diferentes finalidades, como: estudo da rentabilidade da atividade leiteira; redução dos custos controláveis; planejamento e controle das operações do sistema de produção do leite; identificação e 
determinação da rentabilidade do produto; identificação do ponto de equilíbrio do sistema de produção de leite; e instrumento de apoio ao produtor no processo de tomada de decisões seguras e corretas (LOPES; CARVALHO, 2000).

A necessidade de analisar-se economicamente a atividade leiteira é importante, pois, através dela, o produtor passa a conhecer e utilizar, de maneira eficiente e econômica, os fatores de produção (terra, trabalho e capital) e a partir daí, localizam-se os pontos de estrangulamento para depois concentrar esforços gerenciais e ou tecnológicos, para obter sucesso na atividade e atingir os objetivos de maximização de lucros ou minimização de custos (LOPES; CARVALHO, 2000).

De acordo com Reis et al. (2001), por não conseguir controlar o preço do produto que vende, o produtor necessita administrar as variáveis que estão sob o seu controle. Sendo este uma forma gerencial de tornar seu produto competitivo, maximizando seus índices e atingindo menores custos de produção.

Nessa nova realidade, ter controle adequado e, principalmente possuir um sistema de custo de produção de leite, que gere informações para a tomada de decisões rápidas e objetivas são fundamentais para o sucesso da empresa (LOPES et al., 2004).

Neste sentido, o trabalho visa avaliar e discutir os índices financeiros e zootécnicos da Fazenda Olhos D’Água localizada no município de Carmo do Cajuru - MG, no período de janeiro de 2013 a dezembro de 2015.

\section{MATERIAI E MÉTODO}

Para alcançar os objetivos estabelecidos no presente trabalho, foi realizado um estudo descritivo, que é um tipo de estudo utilizado quando necessita obter um melhor entendimento a respeito do comportamento de vários fatores e elementos que influenciam sobre determinados fenômenos (OLIVEIRA, 2004).

A coleta de dados aconteceu de janeiro de 2013 a dezembro de 2015, com ajuda do proprietário da fazenda, guardando todas as notas fiscais e o que não possuía nota foram anotados em um caderno de receitas e despesas da propriedade, além das anotações zootécnicas.

Foram analisados os dados referentes às receitas, despesas, e os índices zootécnicos provenientes de um sistema de produção de leite, localizado no município de Carmo do CajuruMG referentes ao período de janeiro de 2013 a dezembro de 2015. Os dados zootécnicos foram cadastrados no software Prodap-Profissional e os financeiros em tabelas do programa Balde Cheio que tem como objetivo a transferência de tecnologia que contribui para o desenvolvimento da pecuária leiteira em propriedades familiares. 
Foram calculados duas estruturas de custos de produção: custo operacional total, que são a soma dos custos fixos totais e os variáveis totais, e o custo total que está embutido o custo operacional mais o custo de oportunidade (rentabilidade do capital investido). Os custos fixos totais foram calculados a partir de depreciações das benfeitorias, máquinas e equipamentos mais a renumeração do capital dos mesmos, já os custos variáveis foram obtidos através do valor das despesas operacionais geradas, como despesas com alimentação do rebanho, medicamentos, mão de obra, manutenção de máquinas e equipamentos, reparo de benfeitorias, e uma série de despesas de custeio da atividade, a soma de tudo, mais a remuneração do capital atribuído aos custos variáveis obteve-se o custo variável total.

O custo total foi obtido a partir da soma do custo operacional total mais a renumeração dos recursos terra e rebanho (vacas, novilhas e bezerras), pois ambos não foram depreciados. Devido a terra ser um bem que valoriza ao decorrer dos anos, e como a fazenda utiliza o sistema de cria e recria de fêmeas para reposição do plantel, o rebanho também tende a valorizar (LOPES et al.,2004).

O custo operacional efetivo na agricultura familiar pode ser calculado com e sem a remuneração do proprietário. Quando considera o salário do produtor, a fórmula é a seguinte: soma de todas as despesas de custeio do período avaliado que neste caso é de um ano, mais o salário justo ao proprietário, e se divide pela quantidade total de leite produzido. Assim, obtém o custo por unidade produzida.

Ressaltando que não é somente o leite comercializado e sim o leite comercializado somado com leite de descarte e leite para consumo interno.

Custo operacional efetivo (COE) com remuneração do proprietário

\section{$\mathrm{COE}=\underline{\text { Despesas de custeio }+\mathrm{RP}}=\mathbf{R} \$ /$ litro Leite total produzido}

Não considerando o salário do produtor:

Custo operacional efetivo (COE) sem remuneração do proprietário

$$
\mathrm{COE}=\underline{\text { Despesas de custeio }}=\mathbf{R} \$ / \text { litro }
$$

\section{Leite total produzido}

O custo operacional efetivo com equivalente leite é o custo obtido através da divisão das despesas de custeio pela soma da quantidade total de leite produzido mais o equivalente leite que nada mais é que a transformação da receita proveniente da venda de animais (vacas, novilhas, 
bezerras (os) ou outros subprodutos como esterco, ou até mesmo prestação de serviço em outra propriedade, como por exemplo, hora de trator, em valor equivalente ao leite, ou seja, o resultado obtido foi somado à produção efetiva do produto (LOPES e LOPES, 1999).

\section{COE com equivalente leite $=\underline{\text { Despesas de custeio }}=\mathbf{R} \$ /$ litro \\ Leite total produzido+equivalente leite}

O custo operacional efetivo por vaca é obtido pela divisão das despesas de custeio pela quantidade média de vacas que possui no rebanho.

\section{COE por vaca $=\underline{\text { Despesas de custeio }}=\mathbf{R} \$ /$ litro \\ Total de vacas no rebanho}

O custo total é obtido pela divisão das somas de despesas de custeio, depreciações de máquinas, equipamentos e instalações, e a remuneração dos capitais investidos pela quantidade de leite produzido, lembrando que é o leite comercializado somado ao de consumo interno e o de descarte. Assim, encontra-se o custo total por unidade produzida.

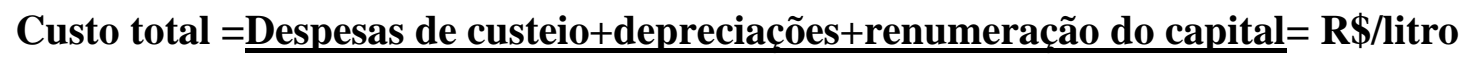 \\ Quantidade total de leite produzido}

O custo total com equivalente leite é a divisão do custo total pela quantidade total produzida somada ao equivalente leite, como explicado no item de custo operacional efetivo com equivalente leite.

Custo total $\mathrm{c} /$ equivalente leite $=\underline{\text { Custo total }}=\mathbf{R} \$$ /litro

\section{Quant. total de leite produzido+equivalente leite}

O custo total por vaca nada mais é que o custo total dividido pelo número total médio de vacas no rebanho no período avaliado.

\section{Custo total por vaca $=$ Custo total $=R \$ /$ vaca \\ Total de vacas no rebanho}

A margem bruta é o resultado da subtração da receita total proveniente da venda do leite, animais, esterco, serviços prestados a terceiros, entre outros, menos o valor das despesas de 
custeio (mão de obra, concentrado, adubos, energia elétrica, mineral, sementes, medicamentos, materiais de ordenha, sêmen, combustíveis, manutenção de maquinas e instalações, telefone, juros, entre outros gastos operacionais.

\section{Margem bruta $=$ Receita total - Despesas de custeio $=\mathbf{R} \$$}

A margem bruta por área é a margem bruta encontrada anteriormente dividida pelo tamanho da área em hectares utilizada para a atividade leiteira.

\section{Margem bruta por área $=\underline{\text { Margem bruta }}=\mathbf{R} \$ / \mathbf{h a}$ \\ Quantidade de ha}

O lucro é o objetivo de todo empreendimento, é o resultado de um trabalho sério e correto, cujo valor é obtido pela subtração da receita total, da soma remuneração do proprietário, das despesas de custeio, depreciações de máquinas, equipamentos e instalações, e remunerações dos capitais investido em animais e terra.

\section{Lucro $=$ Receita total - Custo total $=\mathbf{R} \$$}

O lucro por área é o lucro dividido pela a área em hectares utilizadas na atividade, com este valor podemos observar o quanto de lucro conseguimos ganhar por hectare e comparar com outras atividades que também se utiliza a terra, como a agricultura, a pecuária de corte, entre outras.

\section{Lucro por área $=\underline{\text { Lucro }}=\mathrm{R} \$ / \mathrm{ha}$ \\ Quantidade de ha}

O lucro por litro é o lucro dividido pelo leite total produzido (leite consumo interno+ leite descarte+ leite comercializado).

$$
\text { Lucro por litro }=\frac{\text { Lucro }}{\text { Leite total produzido }}=\mathbf{R} \$ / \text { litro }
$$


O lucro por vaca por ano é o lucro da atividade dividido pelo número médio de vacas no rebanho no período avaliado.

\section{Lucro por vaca ano $=\underline{\text { Lucro }}=\mathbf{R} \$ /$ vaca $/$ Ano.}

\section{Total de vacas no rebanho}

O custo operacional efetivo (COE) dividido pelo custo total e posteriormente multiplicado por 100 é a participação das despesas de custeio (operacionais) no custo total da atividade leiteira.

\section{COE/custo total $\%=\underline{\mathrm{COE}} \times 100$ \\ Custo total}

O custo fixo dividido pelo custo total e multiplicado por 100, é a participação das despesas fixas no custo total da atividade leiteira.

\section{Custo fixo/custo total $\%=\underline{\text { Custo fixo }} \times 100$ Custo total}

A remuneração do capital é a divisão do lucro pelo capital investido, multiplicado por 100 também é conhecida como taxa de retorno do capital investido.

\section{Renumeração do capital total\% $=\underline{\text { Lucro }} \times 100$ \\ Capital investido}

\section{$\underline{\text { Índices Avaliados }}$}

A média da porcentagem da quantidade de vacas em lactação em relação ao número de vacas totais (vacas secas+ vacas em lactação) foi calculada a partir da seguinte fórmula:

\section{Vacas em lactação \%= Vacas em lactação $\times 100$ \\ Total de vacas}

A média da porcentagem da quantidade de vacas em lactação por hectare foi calculada a partir da seguinte fórmula: 
Vacas em lactação por área $=\underline{\text { Vacas em lactaç̃o }} \times 100=$ vacas $/$ há Quantidade de ha

A produtividade por vaca em lactação foi calculada foi calculada a partir da seguinte fórmula:

Produtividade por vaca em lactação $=\underline{\text { Total de leite produzido/dia }}$

Vacas em lactação

A produtividade por vaca do rebanho foi calculada foi calculada a partir da seguinte fórmula:

Produtividade por vaca do rebanho $=\underline{\text { Total de leite produzido/dia }}$

Total de vacas

A porcentagem de vacas no rebanho foi foi calculada a partir da seguinte fórmula:

Vacas no rebanho $\%=\underline{\text { Total de vacas }} \times 100$

Rebanho total

A porcentagem de vacas em lactação no rebanho foi calculada a partir da seguinte fórmula:

Vacas em lactação no rebanho \%= Vacas em lactação $x 100$

\section{Rebanho total}

A produtividade por homem dia é um índice de suma importância dentro da atividade leiteira, este foi calculado a partir da seguinte fórmula:

Leite por homem por dia $\mathbf{1} / \mathrm{h} / \mathrm{dia}=$ Total de leite produzido/dia

$\mathrm{N}^{0}$ de trabalhadores

O índice de produtividade em litros/ha foi calculado a partir da seguinte fórmula:

Produtividade $=\underline{\text { Total de leite produzido no ano }}=$ litros $/ \mathrm{ha}$

Quantidade de há 
A produtividade de litro/ha com equivalência foi calculado a partir da seguinte fórmula:

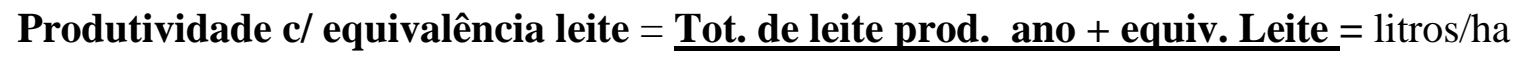

\section{Quantidade de há}

O fluxo de caixa foi desenvolvido a partir da soma de todas as receitas como, receita total provenientes do leite, e equivalente leite menos a despesa total da produção.

\section{Fluxo de caixa $=$ Receita total - despesa total $=\mathbf{R} \$$}

Para calcular o fluxo de caixa por área, utilizou-se o fluxo de caixa calculado na fórmula anterior e dividiu-se pela área em hectares utilizada na atividade leiteira.

\section{Fluxo de caixa por área $=\underline{\text { Fluxo de caixa }}=\mathbf{R} \$ / \mathbf{h a}$ \\ Quantidade de ha}

Para encontrar a receita gerada por cada vaca em um dia, utilizou-se a receita total dividia pela quantidade de vacas médias existentes no rebanho naquele mês, sendo o resultado dividido pelo número de dias do respectivo mês.

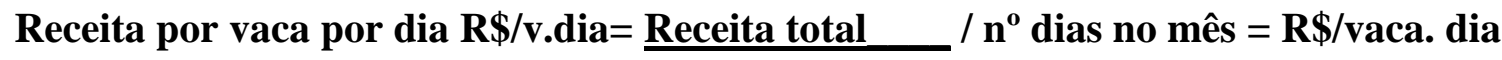 Vacas no rebanho}

Para encontrar a receita gerada por cada vaca no período de um ano, multiplicou-se o valor encontrado anteriormente de receita por vaca dia, por 365 dias do ano.

\section{Receita por vaca por ano $=$ receita por vaca $/$ dia $x 365 \mathrm{dias}=\mathbf{R} \$ /$ vaca. ano}

O valor de depreciações das máquinas, equipamentos e instalações utilizadas no processo produtivo da atividade, é o valor de recuperação do capital empregado nestes fatores de produção. No inventário, foram atribuídos a cada máquina, sua vida útil, o valor inicial e o valor final (residual) da mesma.

O valor da depreciação anual das máquinas encontradas foi dividido por 12 meses do ano, sendo lançado automaticamente na planilha utilizada mês a mês. E o capital investido foi por 6\%, valor este referente à taxa de remuneração da caderneta de poupança, que foi utilizada como parâmetro para os cálculos do custo de oportunidade. 
A remuneração de terras e animais é o valor de oportunidade do capital investido em animais e terra, ou seja, é a remuneração do montante do dinheiro aplicado nestes fatores produtivos. Inicialmente foi realizado o inventário dos animais existentes na fazenda, discriminando categoria por categoria, e atribuindo valor de mercado a cada um, além das terras utilizadas na produção de leite.

Ao somatório atribui-se uma taxa de juros de $6 \%$ ao ano (caderneta de poupança) $\mathrm{O}$ valor encontrado foi remuneração do capital investido em animais e terra, que foi dividido por 12 meses, sendo o resultado lançado automaticamente na planilha mês a mês.

A avaliação patrimonial foi obtida por meio da soma dos valores atribuídos ao patrimônio do proprietário no inventário, como máquinas, equipamento, instalações, animais e terra utilizada na atividade leiteira.

O índice de variação do patrimônio foi obtido a partir da segunda atualização do inventário (máquinas, equipamentos, instalações, animais e terra) em que se obtém a variação (positiva ou negativa) do patrimônio do proprietário em relação ao ano anterior. A comparação foi feita a partir do índice 100, que é tipo um número neutro, a cada $1 \%$ de aumento ou diminuição do patrimônio da fazenda é adicionado ou subtraído do número 100, basicamente para sabermos se houve aumento ou decréscimo no patrimônio em comparação ao ano anterior.

\section{Índice de variação patrimonial = Patrimônio final - patrimônio inicial}

Despesas de custeio/ despesas totais \% foi calculada pela divisão das despesas de custeio pela receita total (venda de leite, animais, serviço para terceiros, etc) multiplicado por 100.

\section{Despesas custeio/despesas totais $\%=\underline{\text { Despesas de custeio }} \times 100$}

\section{Despesas totais}

Reais investido/ litro produzido foi calculado pela quantidade em reais investido (patrimônio) pela produção média de leite (leite vendido, leite consumo interno e leite para as bezerras).

\section{Reais investido/litro produzido $=\underline{\text { Patrimônio }}=\mathrm{R} \$ /$ litro Produção total no ano}

Reais investido por vaca foi calculado pela quantidade em reais investido (patrimônio) pela quantidade total de vacas existentes no rebanho (vacas secas e vacas em lactação). 


\section{Reais investido/vaca $=\underline{\text { Patrimônio }}=\mathbf{R} \$ /$ vaca \\ Vacas no rebanho}

Foram analisados os percentuais que mais e que menos pesaram no custo variável e a comparação dos custos fixos com a variação da produção de leite nos três anos avaliados

Foram feitas comparações dos percentuais gastos em cada item do custo operacional efetivo ao longo desses anos, e realizada uma série histórica de preços médios mensais recebidos pelo produtor, no período de 2013 a 2015.

Para cálculo do custo do "leite virtual", converteram-se todas as receitas, venda de animais e subprodutos, em leite, utilizando-se o preço do leite praticado. O resultado obtido foi somado à produção efetiva do produto (LOPES e LOPES, 1999). A receita da atividade foi constituída pela venda de leite, animais e prestação de serviço de trator.

Os índices zootécnicos analisados foram: intervalo entre partos, percentagem de vacas em lactação em relação ao números de vacas totais e também em relação ao número total de animais no rebanho, produção média diária comercializada, e não comercializada, média de leite por lactação, relação litros de leite por $\mathrm{kg}$ de ração, relação vacas em lactação por funcionário, relação litros de leite por funcionário, produtividade por hectare, produtividade média diária por vaca em lactação, produtividade média diária pelo total de vacas, teor médio de gordura e proteína no leite, média de CCS (Contagem de Células Somática) e CBT ( Contagem Bacteriana Total), idade das fêmeas ao primeiro parto, percentagem de vaca na primeira lactação.

Em cada ano analisado, houve tomadas de decisões diferentes pelo produtor, que refletiu de forma direta e indireta na rentabilidade final da atividade nos anos subsequentes e atualmente.

O método de trabalho utilizado nesta avaliação foi a aplicação do estudo de caso, visto ser o mais recomendado quando se pretende estudar a unidade com mais profundidade (CARVALHO et al., 2009).

\section{RESULTADO E DISCUSSÃO}

A propriedade Olhos D'água tem por objetivo a venda do leite e de bovinos leiteiros. Até o ano de 2014 a propriedade possuía 53,7ha, sendo 13ha destinados ao plantio de milho para silagem safra e safrinha, com rendimento médio dos três anos avaliados de 25,5 toneladas de MS/ha, e uma área de 5 ha de pastagem variadas, de bom valor nutricional.

Porém, esta área foi dividida somente em 5 pastos, onde cada semana as vacas ficam em um, com objetivo de suprir o déficit de matéria seca requerida pelas vacas em lactação, sendo que este 
pastejo representa no máximo 5\% da MS (Matéria seca) total ingerida, estes pastos também servem como área de descanso para os animais na época chuvosa, para evitar que os mesmos deitem no barro.

Nos três anos avaliados, a produção de leite obteve uma grande variação no volume, devido ao fato do produtor optar pela venda de animais produtivos, ou seja, vacas em lactação, e permanecer com animais improdutivos (bezerras, e novilhas), que iriam produzir a curto e médio prazo.

Em 2013 o proprietário da fazenda possuía um montante de financiamento bancário de $\mathrm{R} \$ 100.000,00$ que era pago em parcelas mensais de $\mathrm{R} \$ 4.800,00$ e empréstimos pessoal de $\mathrm{R} \$ 100.000,00$ que era pago somente os juros mensais, ambos com taxa de juros de 1,5\% ao mês,onde todo este valor era retirado da atividade leiteira, visto que esta é a única atividade do produtor. A maioria destes financiamentos foram feitos para adquirir terras de irmãos que receberam na partilha da herança.

Desde o ano de 2008, onde foi adquirido o primeiro financiamento para compra de um terreno, o produtor começou a aumentar o rebanho, vendendo apenas animais de descarte, e com o aumento expressivo da produção em 2010 quando atingiu a marca de dois mil litros de leite diário, foi preciso adquirir bagaço úmido de cervejaria, mais conhecido como cevada, para substituir uma grande parte do volumoso (silagem de milho e pastagem), devido a propriedade não ter mais espaço para produzir volumoso para um grande número de animais.

Em 2011 o bagaço úmido de cervejaria teve um grande aumento no preço por tonelada, juntamente com o frete, contribuindo para a inviabilidade do seu uso na alimentação dos animais, visto que aumentou muito o custo operacional da fazenda, tornando a atividade arriscada, visto que o produtor tinha que pagar todo o custo da atividade, mais o financiamento, somente com a renda do leite. Porém, o produtor continuou aumentando a produção, deixando o número de animais aumentarem, vendendo apenas animais de descarte, com intuito de compensar o gasto com a cevada, tentando diluir os custos no aumento da produção de leite.

Em meados de 2013 a fazenda Olhos D’água bateu o recorde de produção histórica, atingindo dois mil e seiscentos e cinquenta litros de leite diário, com 120 vacas em lactação. Neste mesmo momento, a cevada tem se um segundo aumento, e este de $10 \%$. Como já estava ficando inviável o seu uso e agora com mais este incremento no seu preço, o produtor opta por parar de utilizá-la, e em consequência opta por aumentar o uso de silagem para suprir a alimentação dos animais.

O proprietário passou a cotar preços de outros subprodutos que possa substituir uma boa parte do volumoso requerido pelos animais, e encontra somente a cana-de-açúcar e a silagem de 
milho. Analisando a viabilidade do uso de silagem ou cana- de -açúcar adquiridos de outras propriedades, se torna mais viável utilizar estas duas opções do que a cevada. Porém, o produtor chega à conclusão que não é viável financeiramente ficar comprando volumoso de outras propriedades, mesmo sendo mais em conta que a cevada.

Nessa mesma época, estava havendo uma grande carência de mão de obra na região para trabalhar na atividade leiteira, um terreno vizinho era arrendado para plantio de milho para silagem neste mesmo ano o proprietário resolve a começar uma criação de bovinocultura de corte e pede o terreno. A partir de todos estes entraves ocorridos, falta de mão de obra, propriedade não sustentar a produção de volumoso para o grande número de animais, compra de volumoso e cevada, com preços inviáveis, financiamentos para pagar em curto prazo, e também com o intuito de melhorar a qualidade do leite e redução do índice de mastite do rebanho, o produtor opta por vender mais de $50 \%$ das vacas, e com esta receita desta venda quitar todos os financiamentos, e assim o produtor fez.

Isso fez com que começasse o mês de setembro de 2013 com uma produção diária de apenas 1.050 litros, com essa produção o proprietário não dependia mais de mão de obra permanente, porém os gastos com a criação de bezerras e novilhas pesaram mais no orçamento mensal da atividade, pois diminuiu a receita principal da propriedade que era a venda do leite, e o gasto com alimentação dos animais jovens permaneceram, mas o produtor sabia que em breve a produção iria voltar a subir com estes animais.

O ano de 2014 começou com a produção de 1300 litros de leite diários, sendo o limite que a propriedade suporta com apenas uma pessoa trabalhando, e o proprietário satisfeito com o retorno da atividade. Porém, o mesmo ainda possui dúvida se aumenta mais a produção, se estabiliza ou se diminui, uma vez que as três alternativas eram possíveis de serem realizadas, pois o mercado de venda de vacas em lactação estava aquecido e a propriedade possuía um grande número de novilhas que eram suficiente para reposição do plantel e aumento da produção. Mas, o produtor esperou o mês de junho para tomar tal decisão, pois neste mês colhe-se o milho para silagem da safrinha, e de acordo com a produtividade das lavouras iria escolher o rumo da atividade.

De janeiro a junho a produção se manteve muito estável, em fevereiro foi ensilado a lavoura de milho com uma produtividade dentro da meta, e a safrinha de milho foi plantada com uma adubação pesada para se produzir o necessário para alimentar os animais, caso a decisão fosse aumentar a produção. Entretanto, o clima não ajudou e em junho a meta de colheita da safrinha que era de 37 toneladas de matéria verde por hectare, foi colhido somente 15 . Sendo assim, o produtor teve que optar em diminuição da produção, para não faltar volumoso no final e início do ano. 
Este fato fez com que o produtor vendesse mais 50 vacas entre os meses de julho e setembro, finalizando o ano com uma produção diária de apenas 580 litros de leite.

Em 2015 a produção diária de leite se inicia com apenas 500litros devido reduzir ainda mais o número de vacas em lactação por causa da secagem de 5 vacas no final do mês de dezembro de 2014, e uma queda drástica no preço do leite recebido. Neste ano, o produtor teve que comprar $\mathrm{R} \$ 4.000,00$ de silagem para alimentação do rebanho, e ainda teve um aumento mensal de $\mathrm{R} \$ 1.000,00$ na despesa familiar. Assim, o produtor percebeu que a baixa produção na fazenda era inviável para o seu negócio, e que a proporção de vacas em lactação em relação ao rebanho estava baixa. Diante deste contexto, o produtor teve apenas duas saídas para continuar na atividade, uma era todo mês pegar empréstimo de aproximadamente R \$ 5.000,00 para suas despesas familiares, pois o custo operacional da fazenda era engolido totalmente pela receita proveniente do leite.

E a outra, era vender bezerras e novilhas, que eram animais que não estavam gerando receita e sim despesas, que eram pagas com a renda do leite que a mesma era proveniente somente de $26,4 \%$ de animais de todo o rebanho, que são os animais produtivos, que geram receitas (vacas em lactação), ou seja, uma vaca em lactação tinha que gerar receita para pagar a despesa dela própria, e de mais três fêmeas do rebanho.

Porém, no momento o mercado estava muito frio para a venda de bezerras e novilhas, devido à baixa do preço do leite, então o produtor optou em pegar empréstimo todo mês, mas com expectativa de ser somente no primeiro semestre, uma vez que na propriedade tinha muitas novilhas prenhas, que iria virar vaca e gerar receita.

Assim, ele procedeu com a atividade até o mês de julho, onde a produção diária alcançou 870 litros de leite devido as novilhas prenhas começarem a produzir, e o preço do litro de leite houve um reajuste médio próximos de $10 \%$. Sendo assim, foi possível pagar as despesas de custeio gerais da fazenda e retirar os $\mathrm{R} \$ 5.000,00$ que o produtor necessitava mensalmente para pagar o empréstimo.

Desta forma, não precisou pegar mais empréstimos todo mês. Em setembro quando mais novilhas passaram a produzir leite, a fazenda alcançou uma produção de 1200 litros de leite diariamente. Neste período, a fazenda passou a gerar um fluxo de caixa positivo e essa produção se estabilizou até o final do ano. Entretanto, os empréstimos feitos mensalmente no primeiro semestre não foram pagos, devido ao produtor ter a necessidade de comprar insumos para a próxima safra de milho para silagem, mas em 2016 o produtor pretende pagar estes empréstimos.

A seguir, na Tabela 1 serão apresentados os resultados zootécnicos dos três anos avaliados, referentes aos período de 2013 a 2015 : 
Tabela 1.Resultados zootécnicos dos três anos avaliados

\begin{tabular}{|c|c|c|c|c|}
\hline Discriminação & Unidade & 2013 & 2014 & 2015 \\
\hline Leite comercializado & Litros & 663.208 & 351.617 & 310.893 \\
\hline Leite consumo interno & Litros & 122 & 123 & 180 \\
\hline Leite para as bezerras & Litros & 25.886 & 18.250 & 15.366 \\
\hline Leite total produzido & Litros & 689.206 & 369.979 & 326.439 \\
\hline Média produção diária & Litros & 1.890 & 1.016 & 893 \\
\hline Vacas em lactação & $\mathrm{N}^{\mathrm{o}}$ & 87,3 & 50,4 & 43,3 \\
\hline Vacas secas & $\mathrm{N}^{\mathrm{o}}$ & 21 & 12,5 & 7,8 \\
\hline VL/VS & $\%$ & 79,8 & 79,4 & 84,3 \\
\hline Média por vaca em lact. por dia & Litros/vaca lact/dia & 21,6 & 20,1 & 20,9 \\
\hline Media por vaca por dia & Litros/vacas/dia & 17,3 & 16 & 17,6 \\
\hline Bezerras até 1 ano & $\mathrm{N}^{\mathrm{o}}$ & 65 & 43,4 & 35 \\
\hline Novilhas + de 1 ano & $\mathrm{N}^{\mathrm{o}}$ & 34,3 & 54,5 & 38,9 \\
\hline Touros & $\mathrm{N}^{\mathrm{o}}$ & 2,5 & 1 & 1 \\
\hline Vacas no rebanho & $\%$ & 51 & 38 & 45 \\
\hline Vacas em lac. No rebanho & $\%$ & 41 & 31 & 38 \\
\hline Mão de obra & $\mathrm{N}^{\mathrm{o}}$ & 2,1 & 1 & 1,2 \\
\hline Litros por homem por dia & L/H.dia & 906 & 1.014 & 767 \\
\hline Animais equiv. Leite & Litros & 199.363 & 166.747 & 11.323 \\
\hline Produtividade & L/ha/ano & 10.522 & 5.649 & 4.984 \\
\hline Produtividade com equiv. leite & L/ha/ano & 13.566 & 8.194 & 5.157 \\
\hline Área arrendada & Há & 25 & 25 & 25 \\
\hline Área própria utilizada & Há & 53 & 53 & 53 \\
\hline Área total & Há & 78 & 78 & 78 \\
\hline Gordura & $\%$ & 3,72 & 3,64 & 3,54 \\
\hline Proteína & $\%$ & 3,27 & 3,3 & 3,16 \\
\hline $\mathrm{CCS}$ & Cels./ml x 1000 & 332 & 197 & 179 \\
\hline CBT & Ufc/ml x 1000 & 16 & 18 & 13 \\
\hline
\end{tabular}

Fonte: Próprio autor (2016).

*CCS (Contagem de Células Somáticas)

* CBT (Contagem Bacteriana Total)

* VL/VS (Vaca lactação/Vaca seca) 
Na Tabela 2 a seguir, serão apresentados os índices econômicos referentes aos três anos analisados 2013 a 2015:

Tabela 2.Resultados Econômicos

\begin{tabular}{|c|c|c|c|c|}
\hline Discriminação & Unidade & 2013 & 2014 & 2015 \\
\hline Média de preço & $\mathrm{R} \$ /$ litro & 1,04 & 1,02 & 1,06 \\
\hline Fluxo de caixa & $\mathrm{R} \$$ & $218.899,70$ & $112.849,84$ & $67.726,37$ \\
\hline Fluxo de caixa por área & R\$/há & $2.806,41$ & $1.446,79$ & 868,29 \\
\hline Receita por vaca por dia & R\$/v.dia & 22,52 & 23,27 & 18,64 \\
\hline Receita por vaca por ano & R \$/v.ano & $8.365,09$ & $8.493,56$ & $6.805,19$ \\
\hline Receita por litro & R \$/litro & 1,37 & 1,52 & 1,12 \\
\hline Depreciações de máq. e inst. +RCMI & $\mathrm{R} \$$ & $29.578,27$ & $16.952,96$ & $35.583,26$ \\
\hline $\begin{array}{l}\text { Remuneração capital em terras e } \\
\text { animais }\end{array}$ & $\mathrm{R} \$$ & $82.578,00$ & 80.510 & 84.000 \\
\hline Avaliação patrimonial & $\mathrm{R} \$$ & $1.721 .550,00$ & $1.706 .250,00$ & $1.806 .250,00$ \\
\hline Índice var. patrimonial - ano anterior & índice & & 99 & 101 \\
\hline Índice variação patrimonial $1^{\circ}$ ano & Índice & & 99 & 101 \\
\hline Despesas custeio/receita total & $\%$ & 66,2 & 66,2 & 80,5 \\
\hline Investimento por litro de leite & R\$/litro & 910,87 & $1.679,63$ & $2.023,39$ \\
\hline $\begin{array}{l}\text { Investimento/ vaca (Favor deixar claro } \\
\text { no texto quais foram estes } \\
\text { investimentos). }\end{array}$ & $\mathrm{R} \$ /$ vaca & $15.891,23$ & $27.119,21$ & $35.416,67$ \\
\hline
\end{tabular}

Fonte: Próprio autor (2016).

Serão apresentados nas Tabelas 3 e 4 os resultados econômicos relativos aos anos de 2013 a 2015, considerando estes resultados econômicos sem a remuneração do produtor e com a remuneração do produtor respectivamente: 
Tabela 3.Resultados econômicos sem a remuneração do proprietário

\begin{tabular}{|c|c|c|c|c|}
\hline Discriminação & unidade & 2013 & 2014 & 2015 \\
\hline $\begin{array}{l}\text { Custo } \\
\text { operacional } \\
\text { efetivo }(\mathrm{COE})\end{array}$ & R \$/litro & 0,87 & 0,96 & 0,86 \\
\hline $\begin{array}{l}\mathrm{COE} \text { com } \\
\text { equiv. Leite }\end{array}$ & R\$/litro & 0,67 & 0,66 & 0,83 \\
\hline COE por vaca & $\mathrm{R} \$$ & $5.684,42$ & $5.738,01$ & $5.591,24$ \\
\hline $\begin{array}{l}\text { COE por vaca } \\
\text { em litros }\end{array}$ & Litros & 5.449 & 5.598 & 5.275 \\
\hline Custo total & R \$/litro & 1,03 & 1,11 & 1,22 \\
\hline $\begin{array}{l}\text { Custo total } \\
\text { equiv. Leite }\end{array}$ & R\$/litro & 0,80 & 0,76 & 1,18 \\
\hline $\begin{array}{l}\text { Custo total por } \\
\text { vaca }\end{array}$ & R\$/vaca & $6.571,15$ & $6.519,72$ & $7.827,99$ \\
\hline $\begin{array}{l}\text { Custo total por } \\
\text { vaca litros }\end{array}$ & Litros & 6.299 & 6.361 & 7.380 \\
\hline Margem bruta & $\mathrm{R} \$$ & $306.499,70$ & $180.649,84$ & $67.726,37$ \\
\hline $\begin{array}{l}\text { Margem bruta } \\
\text { por área }\end{array}$ & R\$/há & $3.929,48$ & $2.316,02$ & 868,29 \\
\hline Lucro & $\mathrm{R} \$$ & $194.343,49$ & $124.186,88$ & $-51.856,89$ \\
\hline Lucro por área & $\mathrm{R} \$ / \mathrm{ha}$ & $2.967,08$ & $1.895,98$ & - 791,71 \\
\hline Lucro por litro & R\$/litro & 0,28 & 0,34 & $-0,16$ \\
\hline $\begin{array}{l}\text { Lucro por vaca } \\
\text { por dia }\end{array}$ & R\$/v.dia & 4,91 & 5,41 & $-2,79$ \\
\hline $\begin{array}{l}\text { Lucro por vaca } \\
\text { por ano }\end{array}$ & $\mathrm{R} \$ / \mathrm{v}$.ano & 4,7 & $1.973,83$ & $-1.076,80$ \\
\hline $\begin{array}{l}\text { Lucro por vaca } \\
\text { em litros }\end{array}$ & litros & 1.720 & 5,3 & -859 \\
\hline $\begin{array}{l}\mathrm{COE} / \text { Custo } \\
\text { total }\end{array}$ & $\%$ & 84,2 & 86,3 & 70 \\
\hline $\begin{array}{l}\text { Custo } \\
\text { fixo/custo total }\end{array}$ & $\%$ & 15,8 & 13,8 & 30 \\
\hline $\begin{array}{l}\text { Remuneração } \\
\text { do capital total }\end{array}$ & $\%$ & 11,3 & 7,3 & $-2,9$ \\
\hline
\end{tabular}


Tabela 4.Resultados econômicos com remuneração do proprietário

\begin{tabular}{|c|c|c|c|c|}
\hline Discriminação & Unidade & 2013 & 2014 & 2015 \\
\hline Remuneração & $\mathrm{R} \$$ & 48.000 & 54.000 & 62.400 \\
\hline $\mathrm{COE}$ & $\mathrm{R} \$ /$ litro & 0,94 & 1,10 & 1,05 \\
\hline COE com equiv. Leite & $\mathrm{R} \$ /$ litro & 0,73 & 0,76 & 1,01 \\
\hline COE por vaca & $\mathrm{R} \$ /$ vaca & $5.978,94$ & $6.480,58$ & $6.700,75$ \\
\hline COE por vaca em litros & Litros & 5.732 & 6.323 & 6.322 \\
\hline Custo total & $\mathrm{R} \$ /$ litro & 1,10 & 1,25 & 1,41 \\
\hline Custo total equiv. Leite & $\mathrm{R} \$ /$ litro & 0,86 & 0,86 & 1,37 \\
\hline Custo total por vaca & $\mathrm{R} \$ /$ vaca & $7.014,23$ & $7.378,00$ & $9.045,52$ \\
\hline Custo total por vaca litros & Litros & 6.724 & 7.198 & 8.534 \\
\hline Margem bruta & $\mathrm{R} \$$ & $258.499,70$ & $126.649,84$ & $5.326,37$ \\
\hline Margem bruta por área & R\$/há & $3.946,56$ & $1.933,59$ & 81,32 \\
\hline Lucro & $\mathrm{R} \$$ & $146.343,49$ & $70.186,88$ & $-114.256,89$ \\
\hline Lucro por área & R\$/há & $2.234,25$ & $1.071,56$ & $-1.754,38$ \\
\hline Lucro por litro & $\mathrm{R} \$ /$ Litros & 0,21 & 0,19 & $-0,35$ \\
\hline Lucro por vaca por dia & $\mathrm{R} \$ / \mathrm{v} . \mathrm{dia}$ & 3,70 & 3,06 & $-6,14$ \\
\hline Lucro por vaca por ano & R\$/v.ano & $1.350,86$ & $1.115,55$ & $-2.240,33$ \\
\hline Lucro por vaca em litros & Litros & 1.295 & 1.088 & 2.114 \\
\hline COE/Custo total & $\%$ & 85,2 & 87,8 & 74,1 \\
\hline Custo fixo/custo total & $\%$ & 14,8 & 12,2 & 25,9 \\
\hline Remuneração do capital total & $\%$ & 8,5 & 4,1 & $-6,3$ \\
\hline
\end{tabular}


Podemos observar que houve grandes variações nos resultados zootécnicos e econômicos obtidos, devido às tomadas de decisões do proprietário no segundo semestre de 2013 e meados de 2014, que refletiram diretamente nos anos de 2014 e 2015.

\section{Análise dos índices zootécnicos e econômicos no ano de 2013:}

Gráfico 1. Resultados econômicos sem e com a remuneração do produtor, referente ao ano de 2013

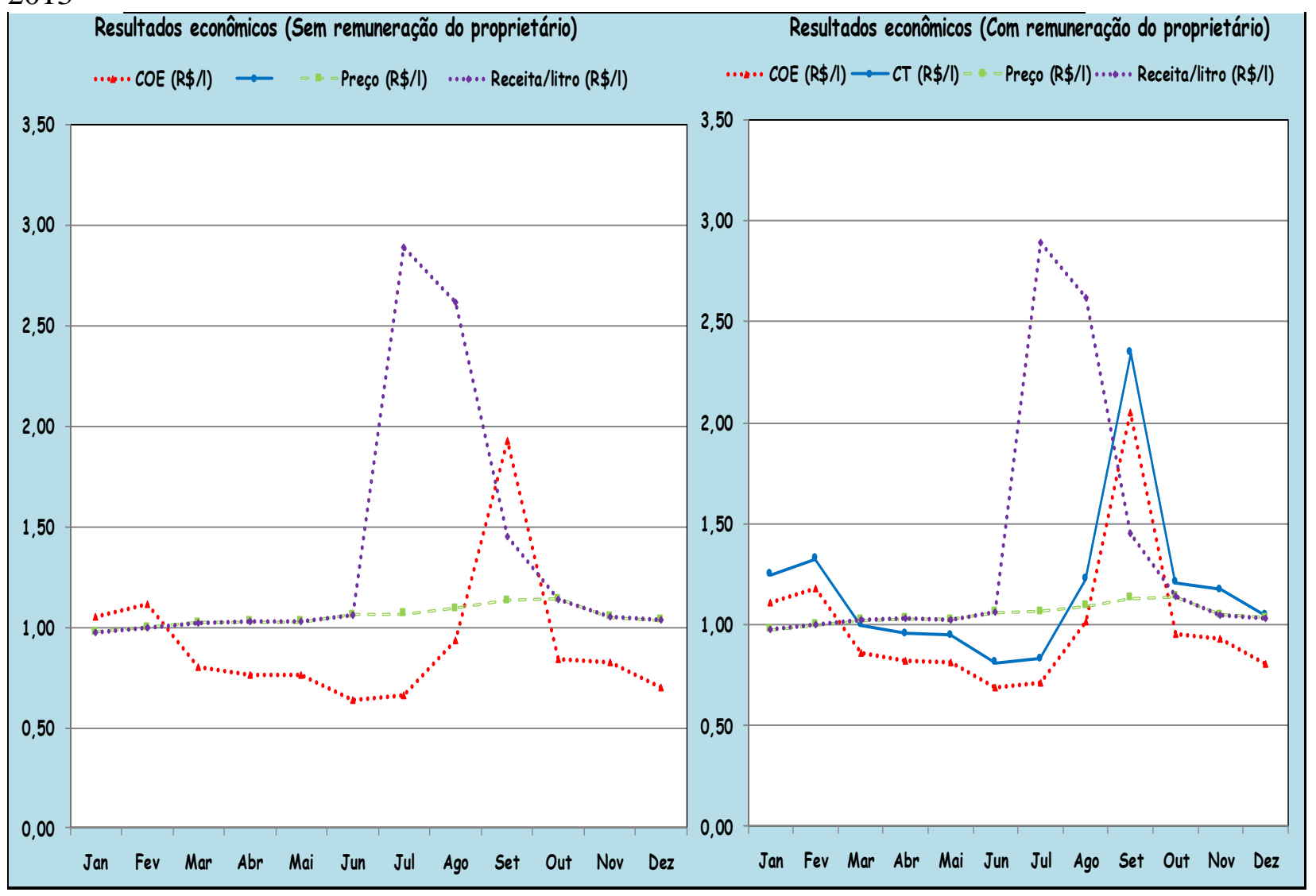

Como podemos observar o Gráfico 1 mostra o custo operacional efetivo, o preço recebido pelo litro de leite e a receita por litro no decorrer dos meses do ano de 2013. Sendo que o gráfico do lado direito considera a remuneração do proprietário que foi de $\mathrm{R} \$ 4.000,00$ ao mês, que significa 6,938\% da receita bruta, proveniente da venda do leite, e o do lado esquerdo sem a remuneração do mesmo.

A receita nos meses de julho, agosto e setembro, foram muito superiores aos demais meses, pelo fato de o produtor ter tomado a decisão em vender um grande número de animais.

O custo operacional efetivo em janeiro e fevereiro foi superior por causa do processo de ensilagem e a compra de insumos para o plantio do milho safrinha. Em setembro este custo foi ainda superior do que a média, chegando próximo de $\mathrm{R} \$ 2,00 /$ litro de leite, devido a dois grandes motivos, primeiro foi a compra de insumos para plantio do milho verão, e segundo pelo fato de ter vendido um grande número de vacas produtiva. Estes fatores tiveram como consequência 
menos volume de leite vendido e menos receita gerada, além de o custeio gerado pelas vacas comercializadas foram pagos neste mês, tudo isso impactou diretamente no custo operacional efetivo. Enquanto que o preço pago pelo litro de leite vendido, não houve uma diferença significativa.

Pode-se observar que a linha no gráfico que representa o custo total só apareceu no gráfico da direita, isso aconteceu porque o programa utilizado para analisar os dados, só calcula o custo total a partir de todos os custos inclusive a remuneração do proprietário.

Gráfico 2.Composição percentual do custo operacional efetivo em 2013

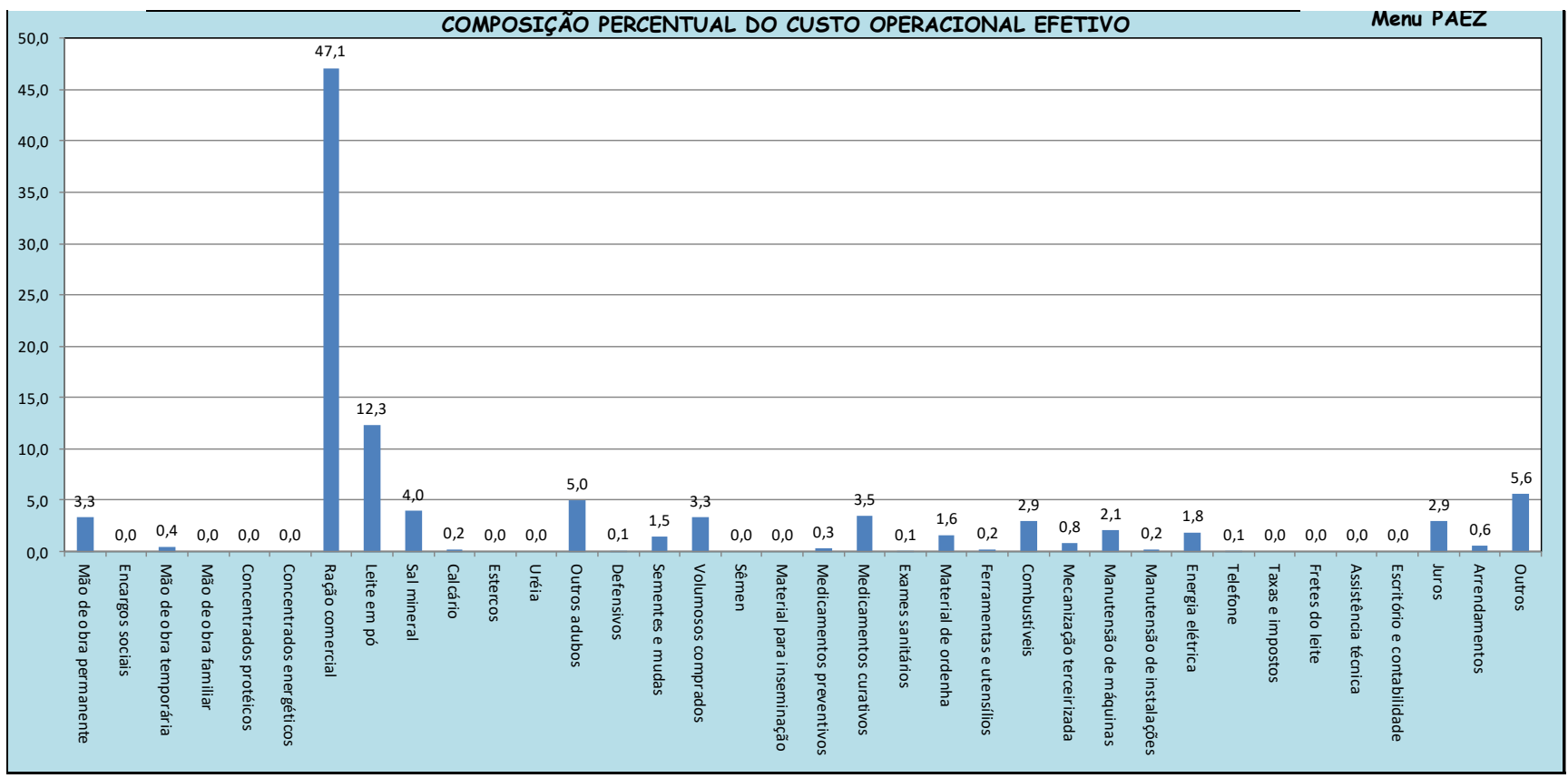

Observa-se com clareza que a maior despesa de custeio dentro da propriedade foi com ração comercial com 47,1\% do custo operacional, seguido pela cevada com 12,5\%, e 12,8\% com a produção de volumoso. A cevada foi utilizada com o intuito de substituir uma parte do volumoso.

Desta forma, fica evidente que $25,3 \%$ do custo operacional efetivo foi gasto somente com volumoso, somando com $47,1 \%$ do concentrado e $4 \%$ com mineral, o produtor teve um gasto de $76,4 \%$ com alimentação do rebanho. Este resultado em uma fazenda com o mesmo sistema de produção, porém eficiente na gestão do negócio, certamente não ultrapassaria 55\% de gasto com alimentação do rebanho.

Este fato foi que levou o produtor a tomar a decisão de parar com o uso de cevada na alimentação dos animais, de vido também ter "sentido no bolso" o alto gasto com alimentação. 
Porém, o produtor tomou decisão a partir do item que gerou o segundo maior custo, que poderia ser reduzido no caso a cevada, e não em relação ao item que gerou o custo mais alto, que era o gasto com concentrado comercial, que geralmente sai em torno de 10 a $15 \%$ mais caro do que se produzisse na própria fazenda.

Gráfico 3.Composição percentual dos animais do rebanho e das vacas em lactação em 2013

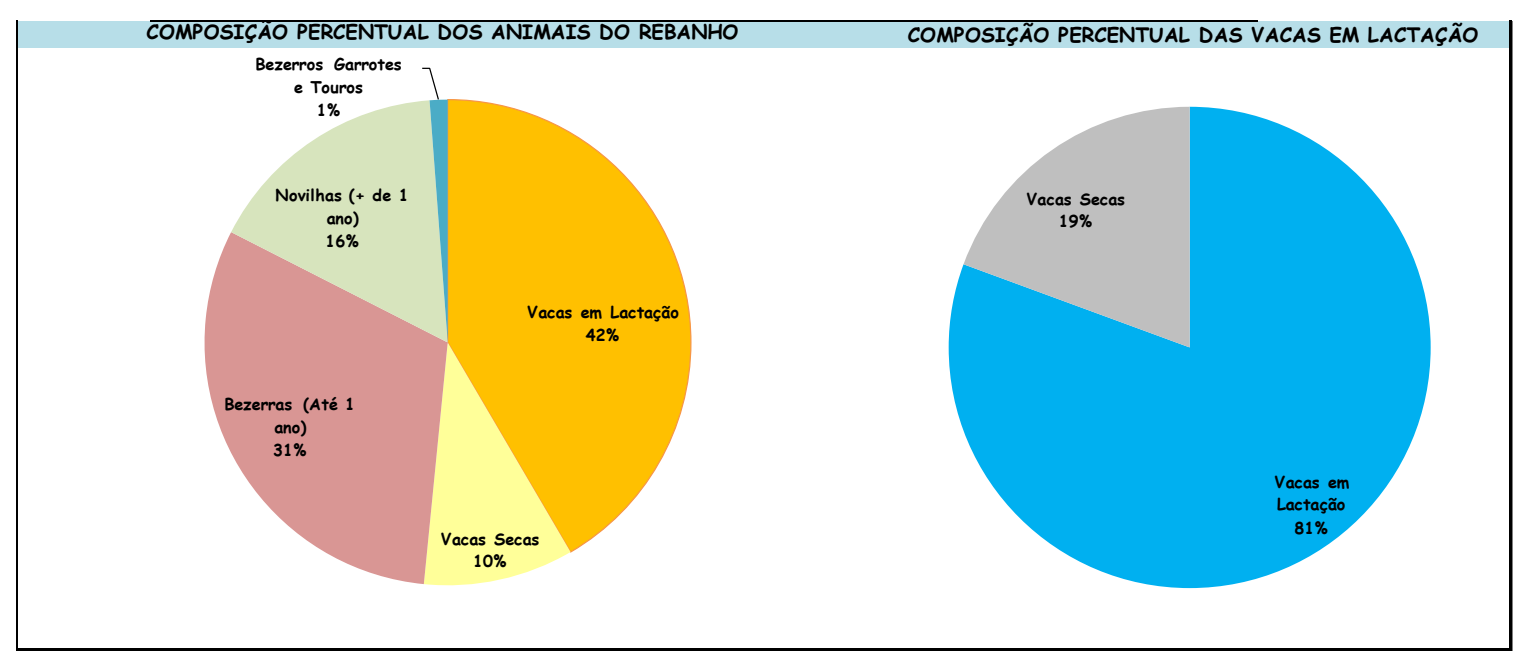

A estruturação do rebanho é um ponto chave em uma propriedade leiteira que precisa de receita para sustentar o seu negócio e sua família, principalmente em época de" vacas magras".

Analisando o Gráfico 3, o da esquerda representa a média de animais em \% no decorrer do ano de 2013, considerando a proporção de cada categoria (bezerras, novilhas, vacas secas, vacas em lactação e touros), em relação ao rebanho total. Vários fatores interferem nesta proporção, como idade ao primeiro parto, intervalo entre parto, persistência de lactação, uso de sêmen sexado ou não, eficiência no manejo e nutrição da cria e recria de bezerras e novilhas, se há venda de animais ou não e em qual categoria comercializa, entre outros.

Por isso, a análise é a seguinte, quanto maior a proporção de vacas em lactação, maior será a receita e menor o custo com a recria, e vice versa. Porém, se a recria não suprir a quantia de descarte e morte de vacas produtivas, o produtor terá que comprar animais para sua reposição, se não sua produção irá diminuir no decorrer dos anos.

No caso da fazenda analisada, se recria todas as bezerras e novilhas, pois o produtor tem como objetivo a venda de vacas produtivas. Os $42 \%$ de vacas em lactação em relação ao total de animais deveria subir para o mínimo de 50\% para diminuir o risco de "passar apertado" nos momentos de crise.

O gráfico da direita representa que $81 \%$ do total de vacas existentes no rebanho estão produzindo, ou seja, estão em lactação gerando receita, um número ideal de vacas em lactação em relação ao total de vacas é $83 \%$, pois este número representa que a persistência e o intervalo entre 
partos estão coerentes com os índices satisfatórios desejados que contribuem para uma boa eficiência produtiva, e os $81 \%$ está bem próximo dos $83 \%$.

\section{Análise dos índices zootécnicos e econômicos no ano de 2014:}

Gráfico 4. Resultados econômicos sem e com a remuneração do produtor, referente ao ano de 2014

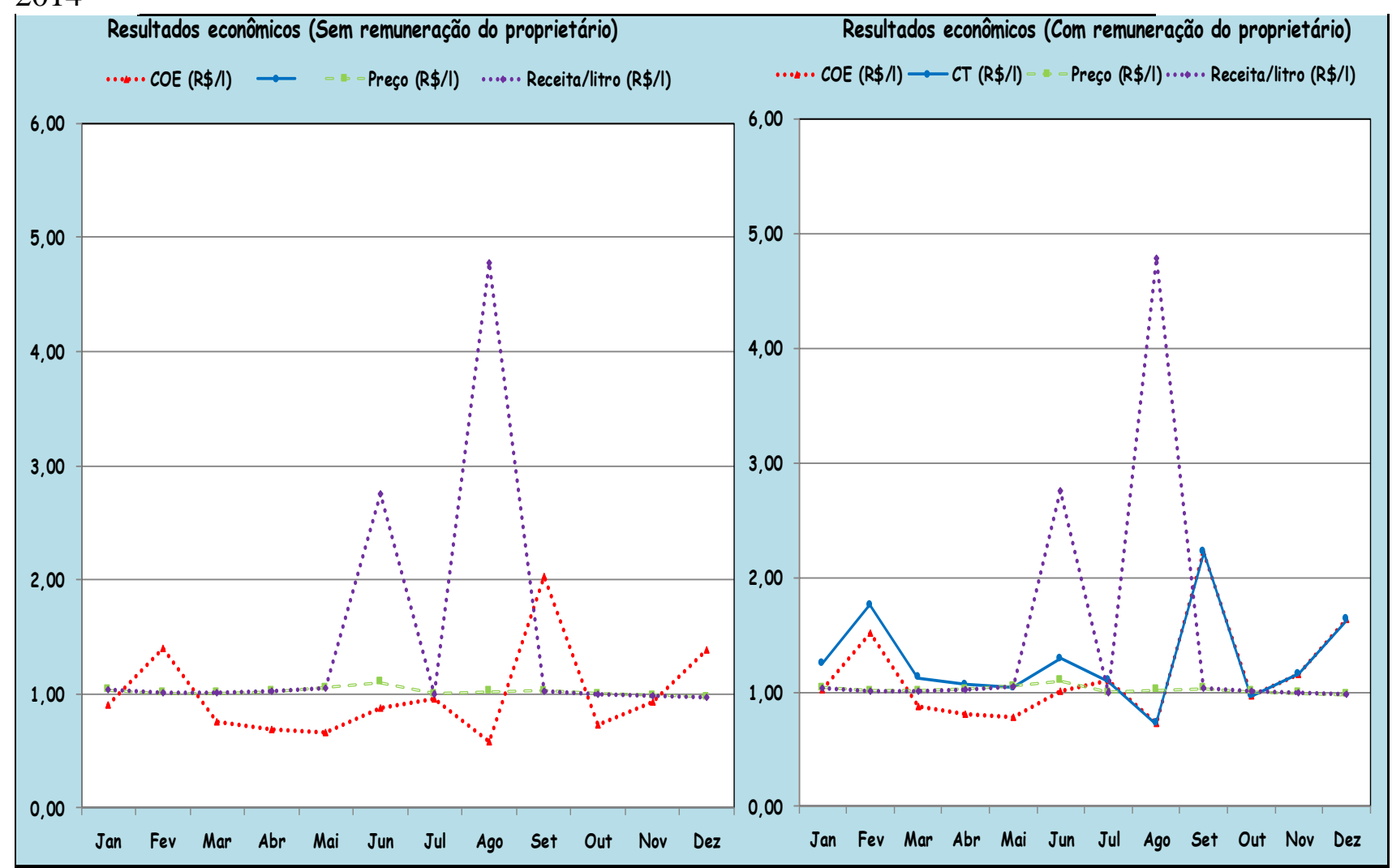

Como pode-se observar no ano de 2014, o custo operacional efetivo, o preço recebido pelo litro de leite e a receita por litro no decorrer dos meses estão representados nos gráficos acima. O gráfico da direita considerou a remuneração do proprietário que foi de $\mathrm{R} \$ 4.500,00$ ao mês, que significa 14,98\% da receita bruta proveniente da venda do leite. A remuneração do proprietário no ano de 2014 aumentou em relação ao ano anterior e a produção de leite comercializada diminuiu praticamente em $50 \%$, isso fez com que o custo operacional efetivo tanto com remuneração do proprietário quanto sem remuneração aumentasse.

As receitas nos meses de junho e agosto, foram muito superiores aos demais meses, em função da venda do grande número de animais.

O custo operacional efetivo em fevereiro e dezembro foi superior por causa do processo de ensilagem e a compra de insumos para o plantio do milho safrinha. Em setembro este custo foi ainda muito superior do que a média, chegando na casa $\operatorname{dos} R \$ 2,00$, foi devido a dois grandes motivos, primeiro foi a compra de insumos para plantio do milho verão e segundo por causa de ter vendido um grande número de vacas produtiva, consequentemente menos volume de leite 
vendido e menos receita gerada, e os custeios gerados pelas vacas comercializadas foram pagos neste mês, tudo isso impactando diretamente no custo operacional efetivo.

Quanto ao preço pelo litro de leite vendido, não houve uma diferença significativa no decorrer do ano. Novamente pode-se observar que a linha no gráfico que representa o custo total só apareceu no gráfico da direita, isso aconteceu porque o programa utilizado para analisar os dados, só calcula o custo total a partir de todos os custos inclusive a remuneração do proprietário.

Gráfico 5.Composição percentual do custo operacional efetivo em 2014

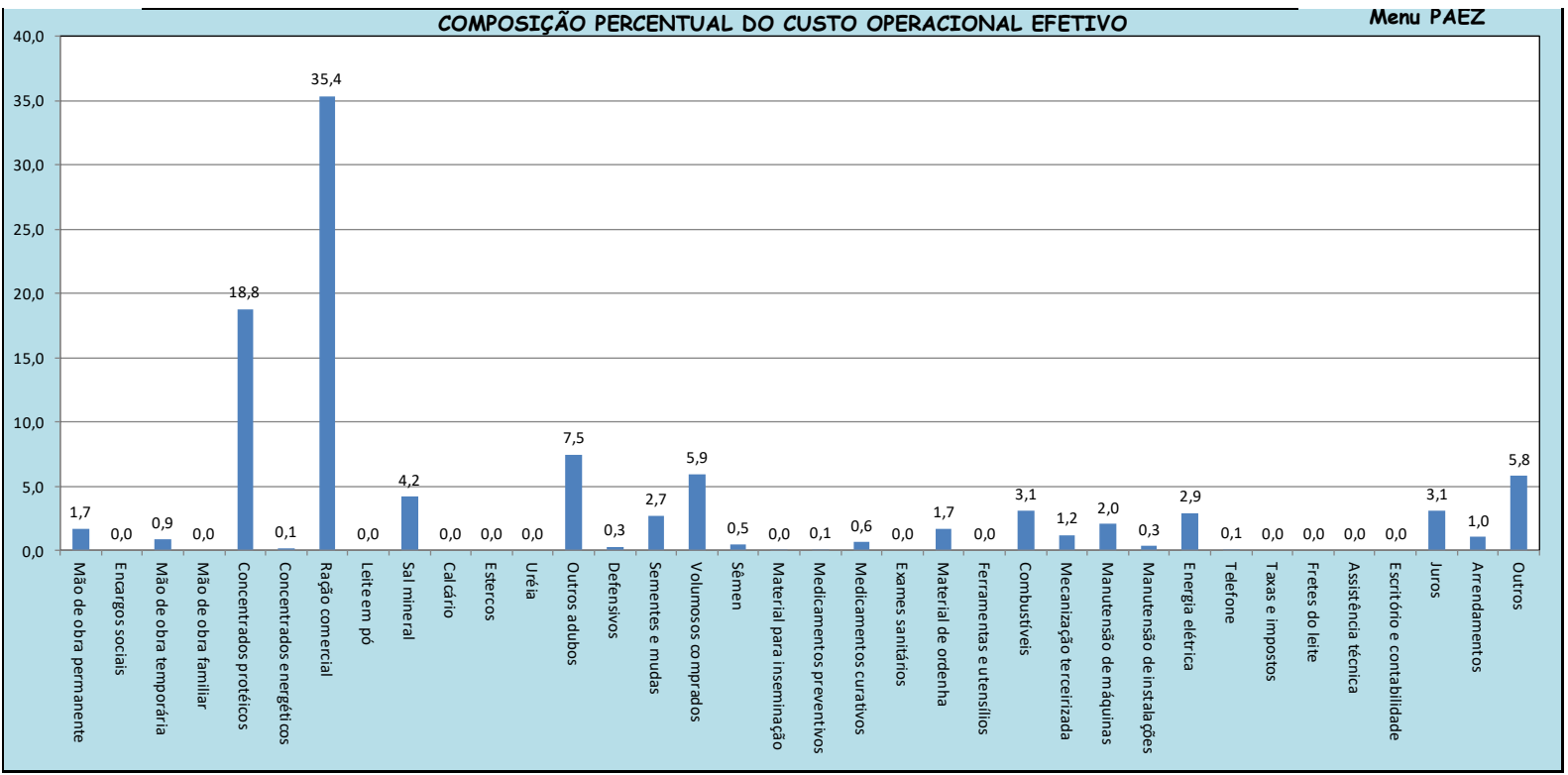

No ano de 2014, observou-se que o produtor atentou mais para o balanceamento da dieta com ajuda do seu filho estudante de zootecnia. Mas, continuou com a compra de ração comercial só que em menor quantidade, pois optou-se pela compra de farelo de soja para adicionar na dieta total dos animais. Isso fez com que o custo por $\mathrm{kg}$ ficasse menor. Apesar, de o custo do concentrado neste ano ter ficado menor do que o ano anterior,o gasto com concentrado com todo o rebanho foi de $54,2 \%$ do custo operacional efetivo, sendo superior aos $47,1 \%$ do ano anterior, pelo fato de no ano de 2013 a proporção de vacas produtivas foram muito inferior, em relação ao número total de animais no rebanho.

Se for somado os gastos com concentrado, mineral e volumoso, obtem-se 77,9\%, também superior ao ano anterior. Mesmo o produtor parando com o uso da cevada para baratear o gasto com alimentação, o gasto foi maior, devido à escassez de chuva período de produção do milho safrinha, que era esperado uma produtividade média de 10,5 toneladas de matéria seca por hectare, e foi ensilado somente 5 toneladas de matéria seca por hectare. Assim, o produtor precisou comprar silagem a um preço superior ao seu custo de produção de silagem. 
Gráfico 6.Composição percentual dos animais do rebanho e das vacas em lactação em 2014 COMPOSIÇAO PERCENTUAL DOS ANIMAIS DO REBANHO COMPOSIÇÃO PERCENTUAL DAS VACAS EM LACTAÇÃO
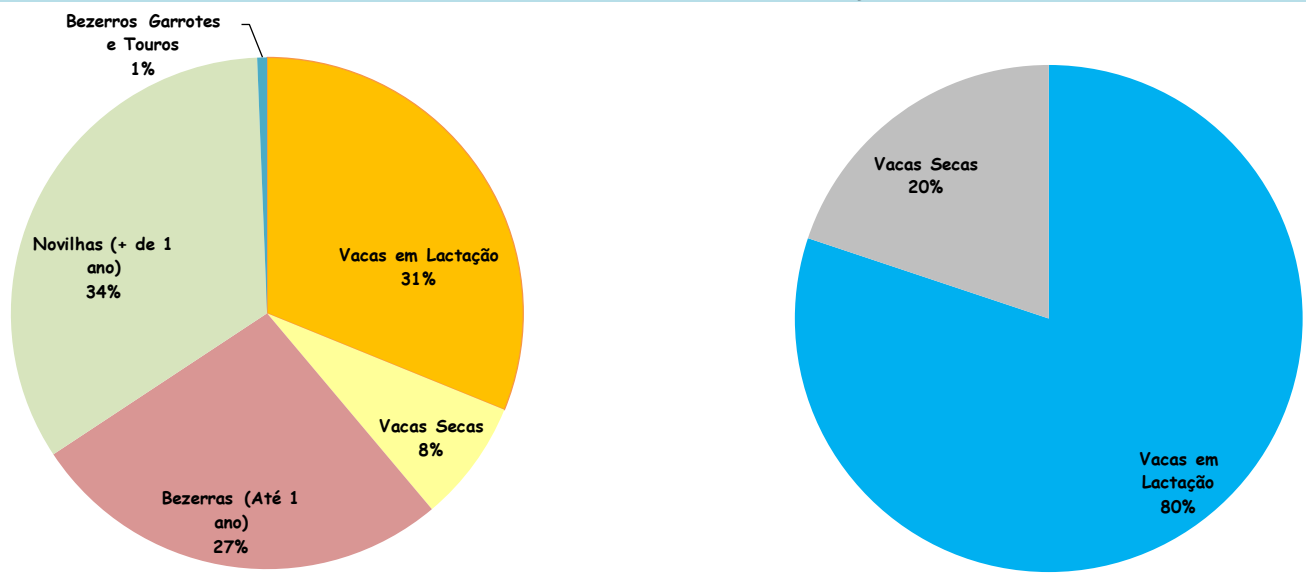

A proporção de vacas produtivas no rebanho diminuiu ainda mais em relação ao ano anterior. Este fato proporcionou um grande impacto no custo de produção, tanto no custo operacional efetivo, por causa de poucos animais terem que pagar as despesas de toda a fazenda, quanto no custo total, devido o maior custo operacional efetivo. Além dos investimentos altos em terras, máquinas e equipamentos. Em contrapartida houve uma redução no volume de leite produzido e em consequência na geração de receitas.

No gráfico da direita podemos observar que a proporção de $80 \%$ de vacas em lactação em relação ao total de vacas está satisfatória. Mas, não podemos analisar esta proporção neste cenário, pois no ano anterior houve um grande desequilíbrio na estruturação do rebanho como um todo, devido a venda de vacas em lactação.

Análise dos índices zootécnicos e econômicos no ano de 2015: 
Gráfico 7.Resultados econômicos sem e com a remuneração do produtor, referente ao ano de 2015

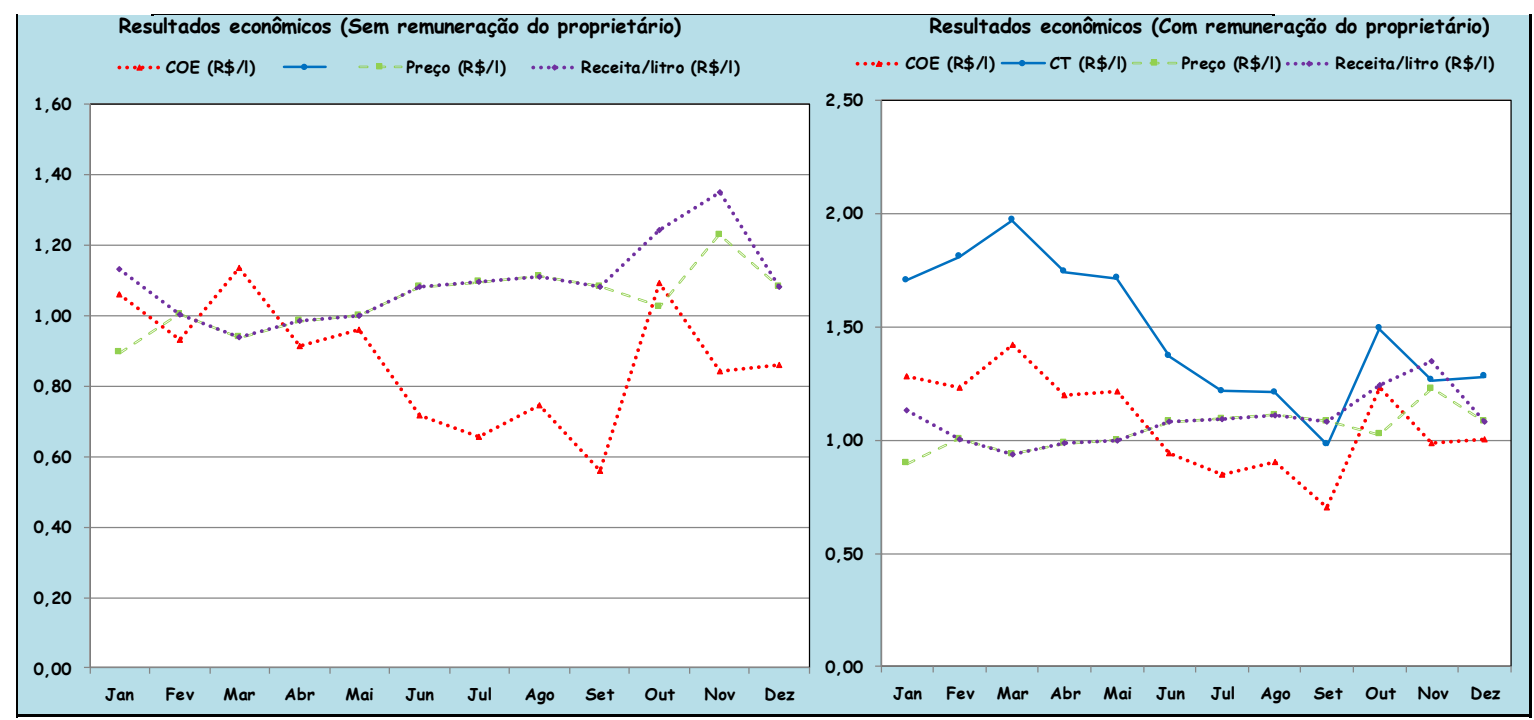

Em 2015, tanto o custo operacional efetivo, preço recebido pelo litro de leite quanto a receita gerada pela atividade, sofreram muita variação no decorrer do ano. O preço do leite variou de $\mathrm{R} \$ 0,90$ a $\mathrm{R} \$ 1,23$. Este valor de $\mathrm{R} \$ 1,23$ no mês de novembro é devido o laticínio que o produtor fornece seu leite, no caso a Danone, bonificar o produtor no mês de novembro em $\mathrm{R} \$ 0,027$ por litro de leite comercializado nos últimos 12 meses, se o produtor atender o mínimo de qualidade exigida pela mesma e não interromper o fornecimento neste período. Este valor acumulado durante todo o ano está incluso no preço do leite no mês de novembro, isso fez com que este valor ficasse bem acima da média.

Gráfico 8.Composição percentual do custo operacional efetivo em 2015

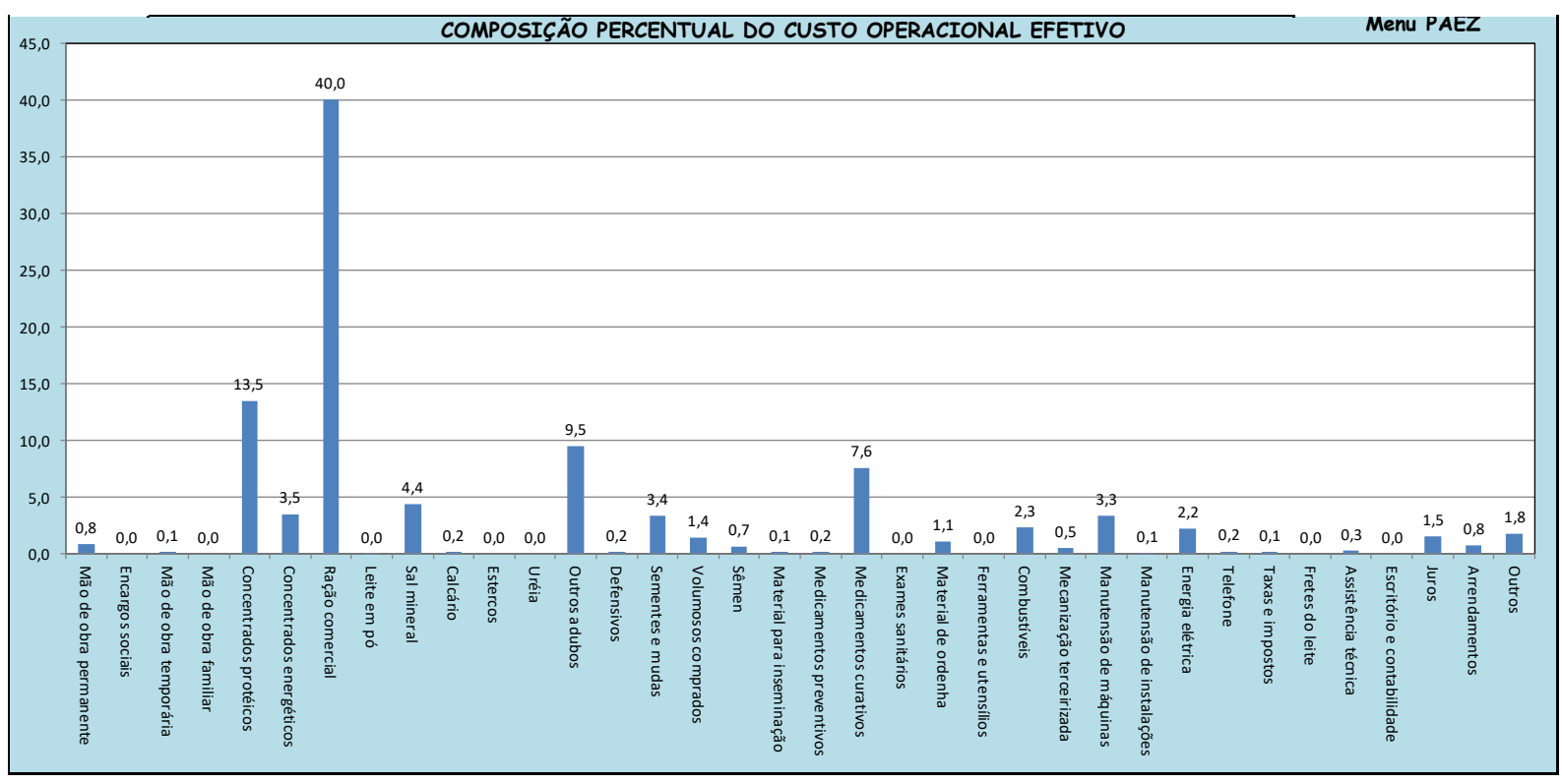


Em 2015 foi um ano dividido em um semestre negativo e o outro positivo, a proporção de gasto com concentrado na alimentação do rebanho foi muito próximo do ano anterior com 53,5\%, e um gasto total na alimentação somando mineral, concentrado e volumoso foi de $72,9 \%$ do custo operacional efetivo. Este valor foi inferior ao do ano de 2014, devido a boa produtividade do milho safrinha para silagem e compra de uma quantia muito inferior de volumosos de terceiros.

Gráfico 9. Composição percentual dos animais do rebanho e das vacas em lactação em 2015

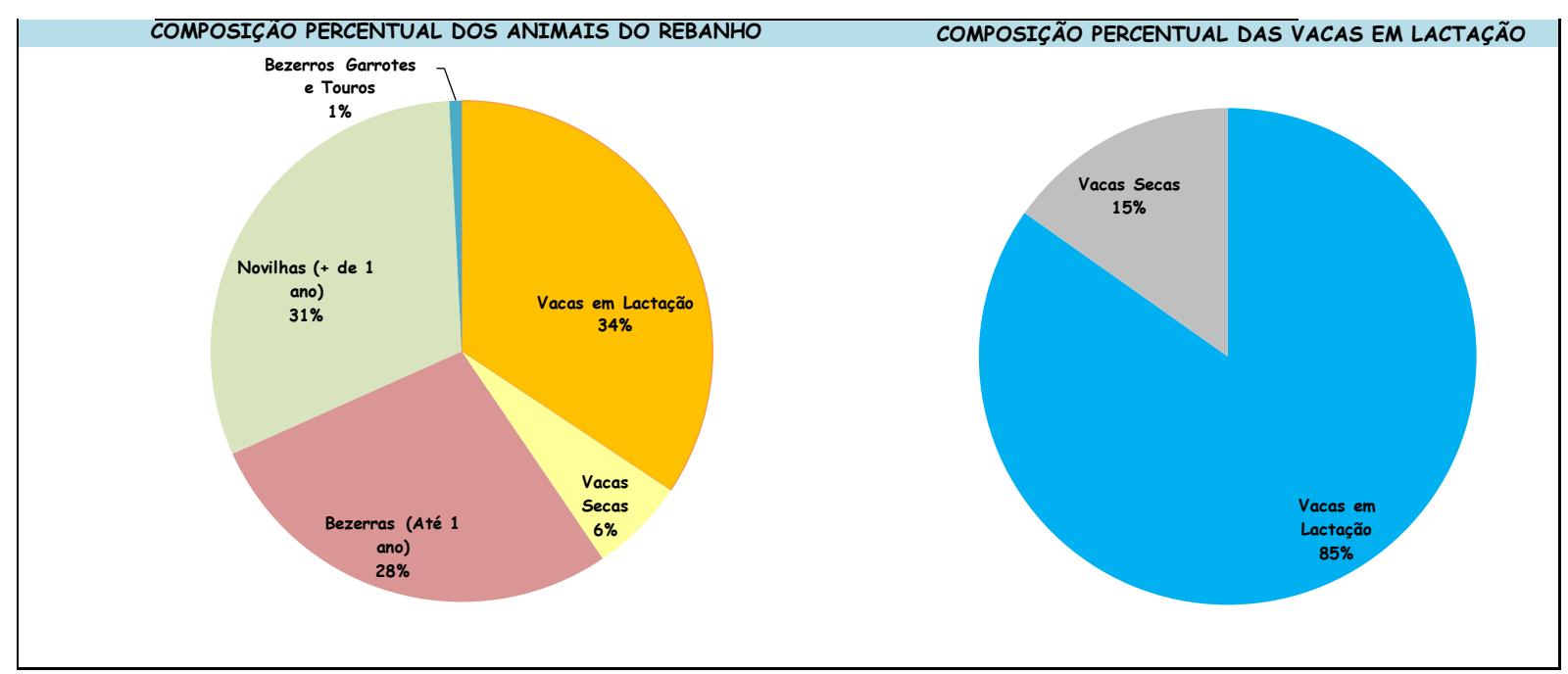

A estruturação do rebanho em 2015 começou péssima, com apenas $25 \%$ do rebanho em produção, ou seja, apenas $1 / 4$ do rebanho estava gerando receita para a movimentação de todo o sistema produtivo, e ainda o preço do leite estava inferior a $\mathrm{R} \$ 1,00$. Isso fez que o primeiro semestre fechasse no vermelho, final do primeiro semestre e início do segundo, os números começaram a sair do negativo e fechar positivo.

Este fato ocorreu, porque grande parte de novilhas passarem a produzir leite, gerando receita e diminuindo gasto com a recria consequentemente. Mas mesmo assim a média de animais em lactação no rebanho fechou bem abaixo do ideal que é de $50 \%$, para se ter uma margem segura de fluxo de caixa proveniente da venda do leite.

No gráfico de azul podemos observar que do total de vacas $85 \%$ eram em lactação, número muito eficiente que também ajudou a fazenda a progredir no segundo semestre.

No período avaliado que foi nos anos de 2013 a 2015, a média do preço recebido pelo litro de leite, foi muito semelhantes, sendo 2013 R \$1,04/litro, 2014 R \$1,02 e 2015 R \$ 1,06, o custo de operacional efetivo (COE)/litro sem a remuneração do proprietário foram, $\mathrm{R} \$ 0,87, \mathrm{R} \$ 0,96$, $\mathrm{R} \$ 0,86$ respectivamente, enquanto o custo total foi de $\mathrm{R} \$ 1,03$ em 2013, $\mathrm{R} \$ 1,11$ em 2014 e $\mathrm{R} \$ 1,22$ em 2015. Pode-se observar que o custo total não teve relação nenhuma com o COE, podemos ressaltar que o menor custo operacional efetivo foi no ano de 2015 e o maior custo total 
do período avaliado, isso ocorreu devido à baixa produção de leite neste ano, alto preço dos insumos no segundo semestre, principalmente dos fertilizantes para o plantio de milho para silagem, e também por causa das depreciações dos recursos permanentes, e a remuneração dos do capital investido na atividade. Todas estes fatos contribuíram de forma significativa no cálculo do custo total, sem contar que os investimentos realizados pelo produtor na atividade foi para uma produção quase três vezes mais do que a ocorrida.

Podemos ver claramente que o custo total em 2013 foi o menor, mesmo com o uso da cevada no primeiro semestre, principalmente por causa do grande volume de leite produzido, que contribuiu para a redução do custo por unidade produzida.

O custo total por vaca em 2013 e 2014 , $R \$ 6.571,15$ e $\mathrm{R} \$ 6.519,72$ respectivamente, não houve quase nenhuma diferença. Mas, em contrapartida em 2015 o custo total por vaca de $\mathrm{R} \$ 7.827,99$ foi superior, evidentemente por causa da pequena relação de vacas em lactação pelo total do rebanho, como dito anteriormente, poucos animais produtivos (em lactação), gerando receita, e muitos improdutivos, que não estavam gerando receitas.

Quanto ao lucro que é realmente o que interessa em qualquer empresa, o ano de 2013 teve um lucro de $\mathrm{R} \$ 194.343,49,2014 \mathrm{R} \$ 124.186,88$ e 2015 fechou em negativo com -R $\$ 51.856,89$.

Com estes números se não tomarmos cuidado ao analisa-los iremos julgar que o ano de 2015 foi péssimo e o ano de 2013 e 2014 foram excelentes. Mas, não podemos analisar desta maneira, é necessário entender os números e as fórmulas de calcular e interpretar os dados. $\mathrm{O}$ ano de 2013 foi o ano com maior lucro, pelo fato de ter ocorrido a venda de muitas vacas em lactação, gerando uma receita extra do leite de $\mathrm{R} \$ 214.400,00$, que foi superior ao lucro, em 2014 de $\mathrm{R} \$ 174.000,00$ também proveniente da venda de animais. Já em 2015 foram vendidos somente $\mathrm{R} \$ 12.300,00$ em animais o que contribuiu para a baixa na rentabilidade deste ano.

Agora se considerarmos somente o custo operacional efetivo, também sem a remuneração do proprietário, iremos encontrar uma margem de R\$0,17/litro em 2013, R\$0,06/litros em 2014 e $\mathrm{R} \$ 0,20$ em 2015, estes valores considera-se somente receita proveniente do leite comercializado, com isso podemos ver que o ano de 2014 foi que teve a menor margem no custo operacional efetivo.

No custo total sem remuneração do proprietário, a margem em 2013 foi o único ano que obteve uma margem positiva, de R\$0,01/litro, em 2014 foi de -R\$0,09 e em 2015 -R\$0,16.Neste caso, o ano de 2015 foi o de menor margem, devido ao fato como dito anteriormente os custos com depreciações e remuneração de capital entrar nos cálculos de custo total e ter contribuído para o aumento do mesmo, além da baixa produção obtida neste ano analisado. Entretanto, o fluxo de caixa que movimenta a atividade, e este foi positivo nos três anos analisados, o que permite o produtor, se manter no negócio e se planejar para os próximos anos. 


\section{CONCLUSÃO}

A eficiência produtiva é e sempre será um ponto chave do sucesso de qualquer empreendimento seja urbano ou rural, sendo um fator decisivo para a competitividade da pecuária leiteira. Para tanto, torna-se necessário uma gestão eficiente e muita cautela na hora de tomar decisões que irá refletir na rentabilidade da atividade em curto, médio e longo prazo.

Na fazenda avaliada, nos anos de 2013 e 2014 grande parte da receita gerada na atividade foi proveniente da venda de vacas em lactação, somente em 2015 que foi a maioria vinda do leite comercializado. Este fato, fez com que a margem bruta, o lucro e consequentemente a rentabilidade do negócio fechasse num valor satisfatório nos dois primeiros anos. Sendo que nestes anos a taxa de retorno do capital foi de $8,5 \%$ e $4,1 \%$ ao ano respectivamente, superior à rentabilidade da caderneta de poupança que é de $6 \%$ ao ano e que foi utilizada como parâmetro de comparação. Já em 2015 essa taxa de retorno foi negativa, fechando em -6,3\%, que significa que se o dinheiro estivesse na caderneta de poupança iria render mais, grosseiramente falando.

Mas, devemos analisar a propriedade como um todo, esta rentabilidade foi negativa, porém a venda de animais foi muito baixa e a taxa de nascimentos foi alta, isto fez com que o capital investido valorizasse $\mathrm{R} \$ 100.000,00$ referente ao ano anterior.

Se jogarmos este valor como receita da atividade, a taxa de retorno negativa de -6,3\%irá passar para -0,75, muito próximo da rentabilidade da caderneta de poupança. Apesar da atividade em 2015 ter proporcionando um retorno inferior ao da caderneta de poupança, o produtor teve uma remuneração de $\mathrm{R} \$ 5.200,00$ que é um valor razoável quando comparamos com a realidade do mercado. Sem contar, que não podemos deixar de considerar a valorização do patrimônio em função dos investimentos realizados.

Diante deste contexto, pode-se concluir que a atividade foi viável nos três anos analisados, mas houve um impacto na sua rentabilidade neste período analisado, porque nem todas as decisões acertadas. Por isso, é necessário focar em uma gestão mais eficiente para que as tomadas de decisões sejam mais embasadas e possam contribuir para o desenvolvimento mais sustentável da atividade.

\section{REFERENCIAIS}

BARDEN, D.S, BOHN, J. D. Influência da assistência técnica e extensão rural no desenvolvimento da pecuária leiteira do município de Mato Leitão - RS. Universidade Tuiuti do Paraná. Santa Cruz do Sul, 2010. 
BRASIL. Ministério Da Agricultura, Pecuária EAbastecimento. Secretaria de Defesa Agropecuária (DISPOA). Instrução Normativa n062, de 26 de agosto de 2003. Oficializa os Métodos Analíticos para Análises Microbiológicas para Controle de Produtos de Origem Animal e Água. Diário da União, Brasília, 26 de agosto de 2003. Seção 1.

FARIA, V. P. Desempenho zootécnico - econômico: Como avaliar. Balde Branco. São Paulo, n. 486, p. 26-29. abril. 2005.

GIL, A. C. Como elaborar projetos de pesquisa. 4.ed. São Paulo: Atlas, 2002.

GOTTSCHALL, C. S., FLORES, A. W., RIES, L. R.; ANTUNES, L. M. Gestão e manejo para bovinocultura leite. Guaíba: Agropecuária, 2002.

GOMES, S. T. Economia da produção do leite. Belo Horizonte: [s.n.], 2000.

IBGE, 2016. Censo Demográfico de 2015. Fundação Instituto Brasileiro de Geografia e Estatística, dados referentes a Produção Animal no $4^{\circ}$ trimestre de 2015. Disponivel em: http://www.ibge.gov.br/home/estatistica/indicadores/agropecuaria/producaoagropecuaria/abateleite-couro-ovos_201504comentarios.pdf. Acessado em: 22,Mai de 2016.

LOPES, M. A.; LOPES, D. D. C. Desenvolvimento de um sistema computacional para cálculo do custo de produção do leite. Revista Brasileira de Agroinformática, v.2, n.1, p.1-12, 1999.

LOPES, M. A.; CARVALHO, F. de M. Custo de produção do leite. Lavras: UFLA, 2000. 42 p. (Boletim agropecuário, 33).

LOPES, M. A.; LIMA, A. L. R.; CARVALHO, F. DE M.; REIS, R. P.; SANTOS, I. C.;

SARAIVA, F. H. Controle gerencial e estudo da rentabilidade de sistemas de produção de leite na região de Lavras (MG). Revista Ciência e Agrotecnologia, Lavras, v. 28, n. 4, p. 883-892, 2004a.

MARION, J C; SEGATTI, S. Sistema de gestão de custos nas pequenas propriedades leiteiras. Faculdade de Economia e Administração da Universidade de São Paulo, 2006

MILK POINT (adaptada por Ascom CALU). IBGE: produção de leite cresceu 2,7\% em 2014; Sul tornou-se a maior região produtora. Disponível

em http://www.calu.com.br/noticias/ver/ibge-producao-de-leite-cresceu-27-em-2014-sul-tornouse-a-maior-regiao-produtora/. Acesso em: 20/05/2016

MILK POINT. Produção por município: MG lidera entre os maiores, 2015. Disponível em: http://www.milkpoint.com.br/cadeia-do-leite/giro-lacteo/producao-por-municipio-mg-tem-maismunicipios-entre-os-maiores-rs-lidera-nas-cidades-com-maior-produtividade-7540n.asp. Acesso em: 20/05/2016.

MILK POINT. O papel da assistência técnica na produção pecuária, 2011. Disponível em: http://www.milkpoint.com.br/radar-tecnico/ovinos-e-caprinos/o-papel-da-assistencia-tecnica-naproducao-pecuaria-introducao-a-tematica-70391n.aspx. Acesso em: 21/05/2016. 
MILK POINT. Gestão de propriedades leiteiras - O que os números tem a dizer? 2014. Disponível em: http://www.milkpoint.com.br/seu-espaco/espaco-aberto/gestao-de-propriedadesleiteiras-o-que-os-numeros-tem-a-dizer-87307n.aspx.Acesso em: 21/05/2016.

NOAL, E. B.; ANCELES, P. E. S.; RIBEIRO, O. D. J. Apuração de custos na pecuária leiteira, um estudo de casos. Dusc. Scientia. Série: Ciências Sociais Aplicadas, Santa Maria, v.1, n.1, p.167-180, 2005

OLIVEIRA, S. LUIZ de. Tratado de Metodologia científica: projetos de pesquisa, TGI, TCC, monografias, dissertações e teses. São Paulo: Pioneira Thomson Learning, 2004. 320 p.

PEREIRA, J.R.A. Evolução da produção de leite no Brasil nos últimos 40 anos.

Pioneer,2013.Disponível;<http://www.pioneersementes.com.br/media-Acesso: 19/05/2016.

RUBEZ, J. Retrospectiva do leite nos anos 90. Associação Brasileira dos produtores de leite, 2011. Disponível em: < http://www.leitebrasil.org.br/artigos/jrubez_040.htm. Acesso em: 19/05/2016.

REIS, R. P.; MEDEIROS, A. L.; MONTEIRO, L. A. Custos de produção da atividade leiteira na região sul de Minas Gerais. Organizações Rurais e Agroindustriais, Lavras, v. 3, n. 2, p. 45-52, 2001.

SANTOS, G.J., MARION, J.C. ; SEGATTI, SONIA. Administração de Custos na Agropecuária. 3. ed. São Paulo: Atlas, 2002.

ZOCCAL, R., CARNEIRO, A.V., JUNQUEIRA, R., ZAMAGNO, M. A nova pecuária leiteira brasileira. In: Barbosa, S.B.P., Batista, A.M.V., Monardes, H. III Congresso Brasileiro de Qualidade do Leite. Recife: CCS , 2008, v.1, p. 85-95. 